\title{
Hurricanes and climate in the Caribbean during the past 3700 years BP
}

\author{
B. Malaizé,' P. Bertran, 2,3 P. Carbonel,' D. Bonnissent, ${ }^{4,5}$ \\ K. Charlier, ${ }^{1}$ D. Galop, ${ }^{6}$ D. Imbert, ${ }^{7}$ N. Serrand, ${ }^{4,8}$ Ch. Stouvenot ${ }^{9}$ \\ and C. Pujol'
}

\begin{abstract}
A multiproxy analysis of lacustrine sediments cored in Grand-Case Pond at Saint-Martin, north of the Lesser Antilles archipelago, reveals three distinct climatic periods for the last 3700 years. From 3700 to $\sim 2500 \mathrm{yr}$ cal. BP and from I I $50 \mathrm{yr}$ cal. BP to the present, carbonate mud deposition occurred in connection with pond lowstands. These periods were also punctuated by severe drought events, marked by gypsum laminae, and hurricane landfalls, leading to marine sand inputs into the pond. The intermediate time interval, from 2500 to II $50 \mathrm{yr}$ cal. BP, is typified by black organic mud deposition, suggesting that hypoxic to anoxic conditions prevailed at the pond bottom. These were probably linked with a perennial pond highstand and reflect more uniform and wetter climatic conditions than today. The carbon isotopic composition of the ostracod Perissocytheridea bisulcata shows that the lowest $\delta^{13} \mathrm{C}$ values are recorded during the hypoxic periods, as a consequence of bacterial recycling of isotopically depleted organic matter. Such a climatic history agrees closely with that documented from other records in the Caribbean area, such as the Cariaco Basin, central coast of Belize or Barbados. By constrast, discrepancies seem to emerge from the comparison between hurricane activity recorded at Saint-Martin on the one hand and Vieques (Puerto Rico) on the other hand. We explain this apparent contradiction by a balance between two distinct storm paths in response to latitudinal shifts of the Intertropical Convergence Zone (ITCZ). Stronger storm activity over the Gulf coast and the inner Caribbean Sea is favoured by a southern position of the ITCZ in connection with dry climatic conditions. Plausible links with the North Atlantic Oscillation (NAO) are also suggested.
\end{abstract}

\section{Keywords}

Caribbean sea, coastal lake, hurricanes, late-Holocene climate, ostracods, Saint-Martin island, stable isotopes

\section{Introduction}

To reconstruct patterns of hurricane activity before the time window documented by instrumental and written archives, and better anticipate future variations, sedimentary archives preserved in coastal lakes have proved to be of great interest. Following the pioneer work of Emery (1969), reliable millennial-scale records of extreme events have been obtained from sediment cores in littoral lakes along the coasts of the Gulf of Mexico and the Antilles (Bertran et al., 2004; Donnelly, 2005; Donnelly and Woodruff, 2007; Lambert et al., 2003, 2008; Liu and Fearn, 1993, 2000; McCloskey and Keller, 2009; Woodruff et al., 2008a, b). These records often extend back to $4000-5000$ years, i.e. the Holocene period of maximum sea level and correlative stabilisation of the coastline (Angulo and Lessa, 1997; Milne et al., 2005). In the cores, hurricane landfalls are identified as sand layers within the lake mud, due to overwash of the coastal sand barrier by storm waves. All the records show clustering of the storm layers within particular time intervals. As stressed by Bertran et al. (2004), an opposite pattern of hurricane activity seemed to emerge from comparison between the records of the Gulf of Mexico and that of Saint-Martin island in the Lesser Antilles. The period 2300-1000 $\mathrm{yr}$ cal. BP was shown to concentrate most of the intense hurricane landfalls in the former, while it corresponds to a lower-than-average activity interval at Saint-Martin. Therefore, it was suggested that little variation in hurricane activity took place during the Holocene at a global scale, but shifts in prevailing hurricane tracks due to fluctuations in the position of air masses occurred. The factors involved in such fluctuations still remain poorly understood, and the possible role of the latitudinal shift of the InterTropical Convergence Zone (ITCZ) was proposed after Liu and Fearn (2000). Since 2004, new palaeohurricane records have been retrieved from Vieques island, Puerto Rico (Donnelly and Woodruff, 2007; Woodruff et al., 2008b), Belize (Gischler et al., 2008; McCloskey and Keller, 2009), and the US Atlantic coast (Donnelly et al., 2004; Mann et al., 2009), increasing significantly the set of available data for comparison. Meanwhile, Liu and

'EPOC, Université de Bordeaux I, France ${ }^{2}$ INRAP, Pessac, France

${ }^{3}$ PACEA, Université de Bordeaux I, France

${ }^{4}$ INRAP, Guadeloupe, France

${ }^{5}$ LAMPEA, France

${ }^{6}$ GEODE, Université Toulouse Le Mirail, France

${ }^{7}$ Université Antilles-Guyane, France

${ }^{8}$ Muséum National d'Histoire Naturelle, France

'Service Régional de l'Archéologie, France

Received 19 March 2009; revised manuscript accepted 24 November 2010

\section{Corresponding author:}

B. Malaizé, EPOC, Université de Bordeaux I, UMR 5805 CNRS,Avenue des Facultés, 33405 Talence, France.

Email:b.malaize@epoc.u-bordeauxI.fr 

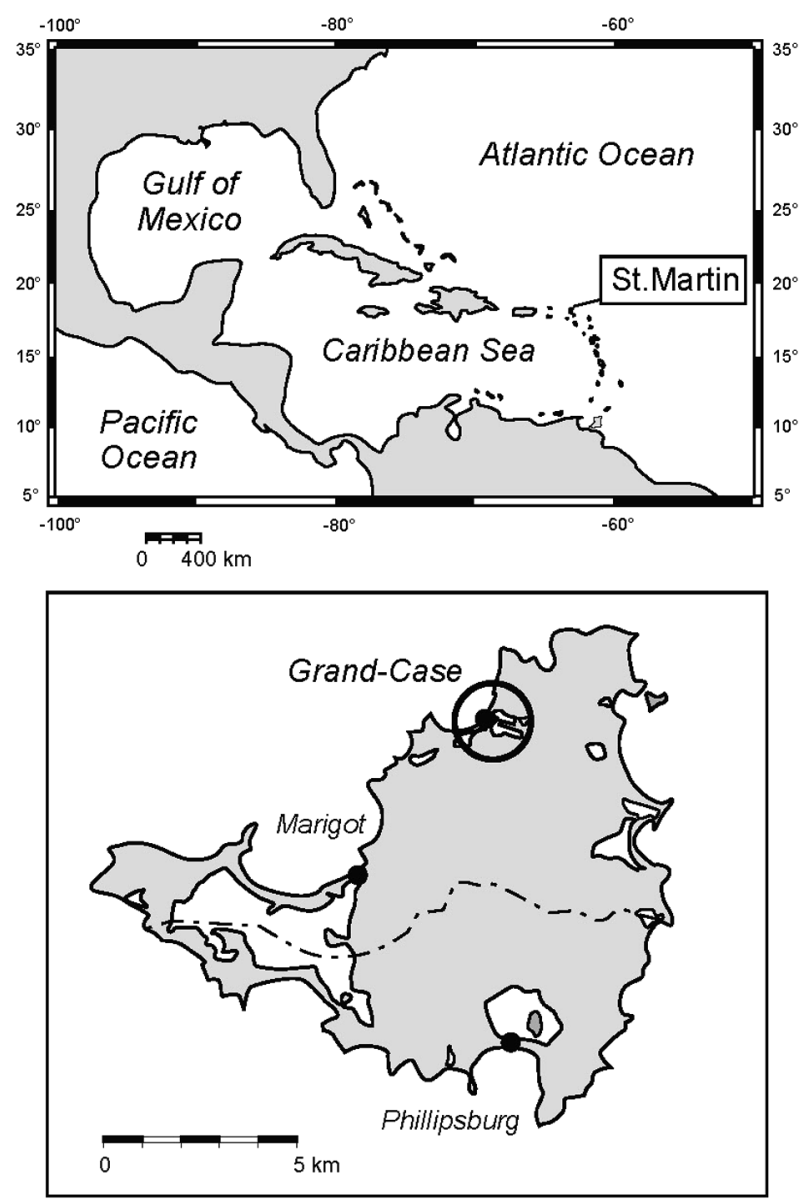

Figure I. Map of Saint-Martin island and location of the study site (Grand-Case Pond)

Fearn reconstructions have been criticized in the literature with respect to both time control (Aharon and Lambert, 2009) and record significance (Otvos, 2002, 2005). The predominant role played by warming of the Atlantic surface waters and associated La Niña-like climatic conditions on the millennial-scale variations of hurricane activity has also been proclaimed by Mann et al. (2009).

Since the Saint-Martin record may be of crucial interest to understand the factors involved in hurricane variability because of its southeastern location $\left(18^{\circ} 5^{\prime} \mathrm{N}, 63^{\circ} 5^{\prime} \mathrm{W}\right)$, new investigations were undertaken here. We present a multiproxy analysis of a new sediment core retrieved from Grand-Case Pond, located on the northern part of the island (Figure 1). Grand-Case Pond (46.7 ha) is a shallow, warm polymictic littoral lake located at the outlet of one of the largest catchments of Saint-Martin, and isolated from the sea by a $200 \mathrm{~m}$ wide wave-built sand barrier (Figure 2). Because of the low tide range $(\leq 40 \mathrm{~cm})$, the inlet is almost continuously closed except during storm surges. The pond is characterised by shallow depth $(\sim 1.5 \mathrm{~m})$ and significant seasonal fluctuations of the water level, although limited today because of regulation by an artificial channel. These fluctuations were obviously larger in the past, and rainstorm-induced amplitudes up to 5 $\mathrm{m}$ are reported in other unmodified ponds at Saint-Martin. Salinity is usually low and ranged between 12 and $29 \mathrm{~g} / \mathrm{l}$ in recent years (2005-2006). However, evaporative concentration of the brine is known to occur during exceptional droughts, and the shallowest part of the pond was dedicated to salt production by the

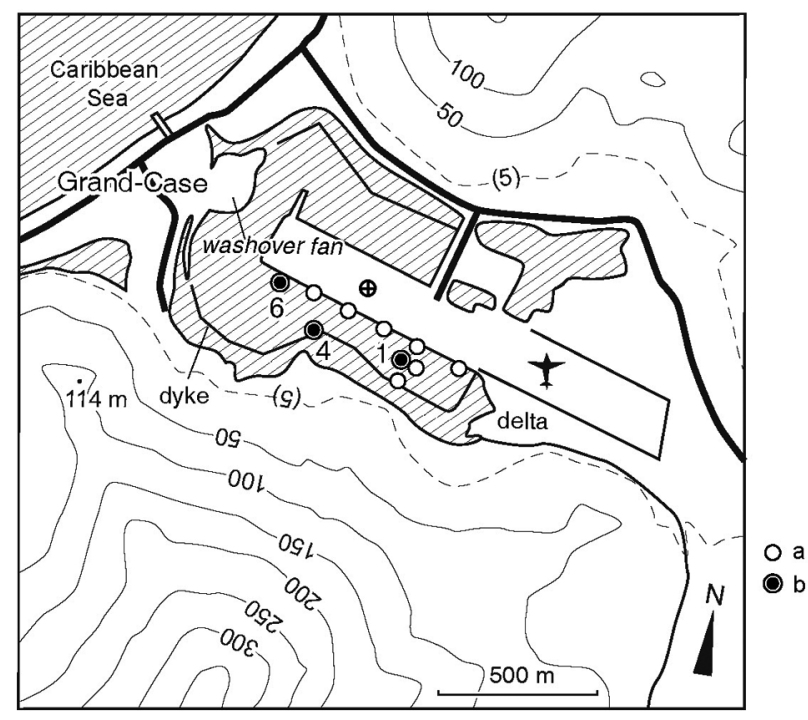

Figure 2. Topography of Grand-Case Pond and core location. a, Penetrometer; b, Russian corer

inhabitants during the eighteenth and nineteenth centuries (Association Archéologique Hope Estate, 1996).

The general stratigraphy shows that black muds develop mostly to the west, in the deepest part of the pond, whereas signs of emergence (oxidized mud, desiccation cracks) appear to the east (Figure 3 ). Mud ( $2.5 \mathrm{~m}$ thick) overlies sandy deposits $(\sim 1$ m) with abundant shell fragments (mainly Anomalocardia brasiliana and Batillaria minima) indicating open lagoonal environments, and coarser-grained material $(>3 \mathrm{~m})$ corresponding to pre-transgression fluvial/mudflow deposits.

One of the interesting aspects of the Grand-Case Pond record is the opportunity to obtain palaeoclimatic information from the lacustrine deposits, which gives insight into the possible links between regional climate and hurricane activity. Preliminary sedimentological study on a first core (GC4) allowed the recognition of three main phases in the hydrological budget of the pond (Bertran et al., 2004): (1) a dry period from 4500 to $2350 \mathrm{yr}$ cal. BP, characterised by the deposition of carbonate mud and gypsum layers, (2) a wet phase (2350-1100 yr cal. BP) dominated by pyrite-rich organic mud in connection to lake highstands, and (3) an overall dry phase (1100 yr cal. BP to the present), with carbonates, gypsum and detrital inputs due to human activities. Most storm layers occurred during the interval 4500 to $2350 \mathrm{yr}$ cal. BP, which was thought to indicate a connection between drought at Saint-Martin and high hurricane frequency in this area. In this paper, we present analytical results obtained on a new core (GC6), retrieved closer to the centre of Grand-Case Pond than the previous cores (GC1 and 4), that provides information on both hurricane frequency and the isotopic composition $\left(\delta^{18} \mathrm{O}\right.$ and $\left.\delta^{13} \mathrm{C}\right)$ of the shells of the ostracod Perissocytheridea bisulcata TEETER, and makes possible deeper understanding of the climatic history of Saint-Martin.

\section{Materials and methods}

The $2.5 \mathrm{~m}$ long GC6 core was retrieved with a Russian corer (diameter $80 \mathrm{~mm}$ ), c. $200 \mathrm{~m}$ east from GC4, in the central part of the pond. The core was sampled with a $2 \mathrm{~cm}$ resolution for 


\section{Caribbean Sea}

\section{E}

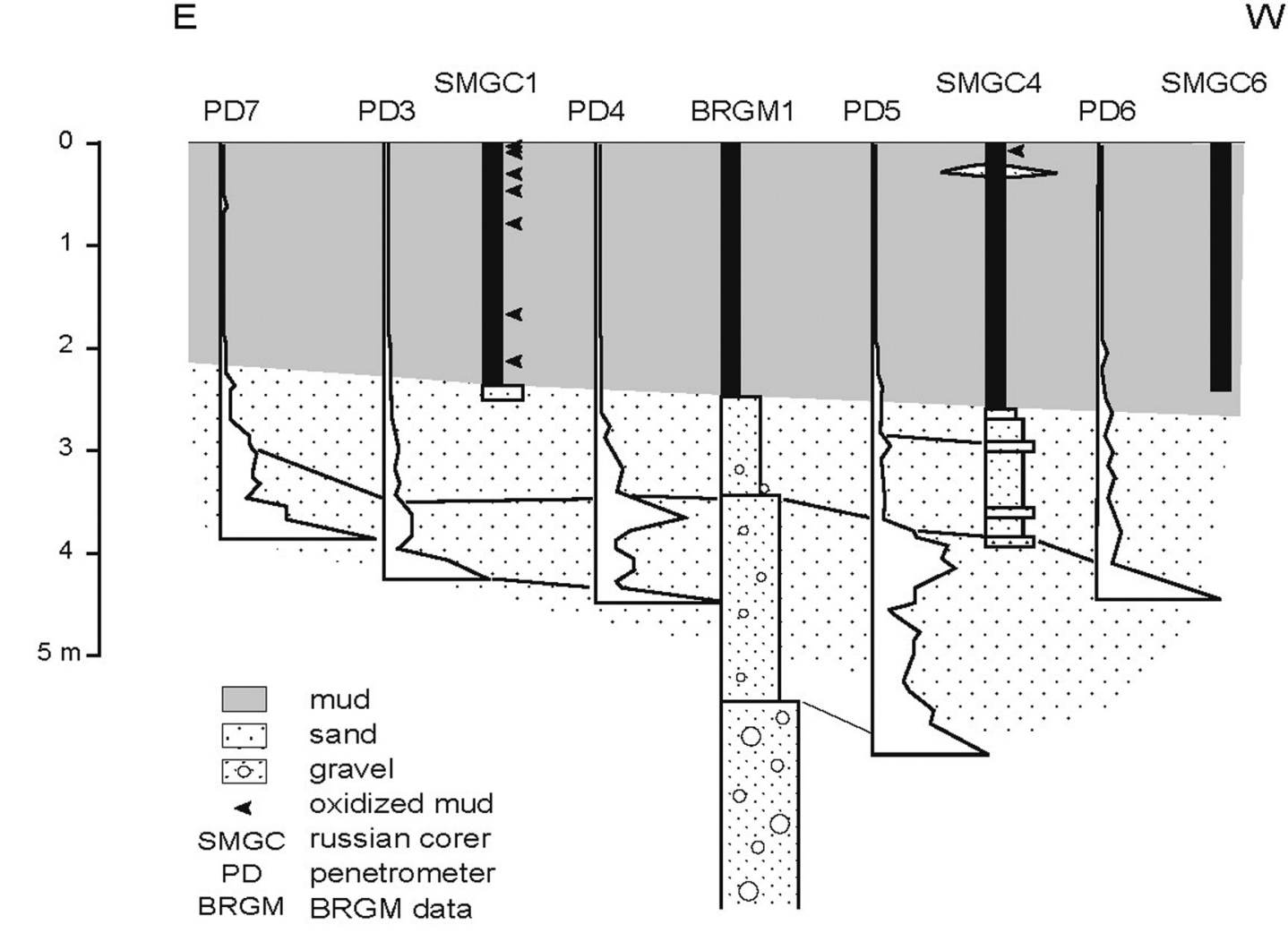

W

Figure 3. Schematic cross section of the lake infilling. PD, penetrometer; BRGM, cores made by the Bureau de Recherche Géologique et Minière, France; SMGC, cores used for this study (GCI, GC4 and GC6)

grain-size analysis, total organic carbon (TOC), carbonate $\left(\mathrm{CaCO}_{3}\right)$ and sulphur content (S) measurements, and ostracod shell counts at the University of Bordeaux 1. Grain-size analysis was undertaken using a laser granulometre (Malvern Mastersizer S) after removal of the organics by $\mathrm{H}_{2} \mathrm{O}_{2}$. TOC, $\mathrm{CaCO}_{3}$ and $\mathrm{S}$ were measured by pyrolysis $\left(1500^{\circ} \mathrm{C}\right)$ coupled with infrared spectrometry with a Leco CS-125 analyzer. Thin sections were made from undisturbed samples taken from a twin core, after lyophilisation and vacuum-impregnation with a polyester resin. Specific lithofacies were also sampled for examination under SEM and x-ray analysis on powder. The diffractograms were recorded from $2.5^{\circ}$ $2 \theta$ to $35^{\circ} 2 \theta$ with scanning steps of $0.025^{\circ} 2 \theta$ and counting time of $3 \mathrm{~s}$ on a Siemens Kristalloflex D500 diffractometer. In most of the core, for each layer, four to five different ostracod species were found (Carbonel, 2006; Carbonel et al., 2007). All species were counted independently, leading to the general abundance curve given in Figure 4. In addition, following promising analyses on ostracod shells in GC4 core, the ostracod species Perissocytheridea bisulcata was selected for isotopic analysis. A minimum weight of $80 \mu \mathrm{g}$ (i.e. $\sim$ four individuals) was necessary for each analysis. When the abundance of Perissocytheridea bisulcata was too low, two subsequent samples were analyzed as a unique level (e.g. at 88-91, 98-103, 212-217, 220-223 and 234-237 cm). After cleaning with distilled water, the ostracods were analyzed and the results were calibrated against PDB using international NBS19 standard. All the analyses were undertaken at the University of Bordeaux 1, using a Micromass Multiprep autosampler associated with an Optima mass spectrometer. Standard deviation of multiple replicate measurements of the standard is 0.035 and 0.045 per mil for $\delta^{13} \mathrm{C}$ and $\delta^{18} \mathrm{O}$, respectively.

Fruits of Ruppia maritima, an aquatic phanerogam, were sampled for AMS- ${ }^{14} \mathrm{C}$ dating at the Vienna Institute for Isotopes and Nuclear Physics, Austria. Previous comparison between the radiocarbon ages given by wood fragments and Ruppia fruits in the GC4 core did not reveal any significant reservoir effect (Bertran et al., 2004). Control of the reservoir effect was only possible in the middle part of the core thanks to the preservation of wood fragments resulting from sedimentation in anoxic bottom waters. Since terrestrial material was not preserved in the rest of the core, lack of variations of the reservoir effect upon time is impossible to ascertain, but such variations are assumed to be of minor importance. The six dates show that the record covers the last 3700 calibrated years (Table 1), with a mean sedimentation rate of c. $0.7 \mathrm{~mm} / \mathrm{yr}$. However, erosive contacts at the bottom of some storm sand layers suggest that temporal gaps may be present in the record, although probably minor.

\section{Results}

\section{Sedimentological setting}

Five main lithofacies are observed in the GC6 core (Figures 4, 5).

(1) Black organic mud. In thin sections, it appears as pyriterich, organic clay with few scattered carbonate pellets and algal filaments. Vegetal macrofossils are mainly fragments of lignified terrestrial plants, while Ruppia maritima fruits are lacking or rare. 


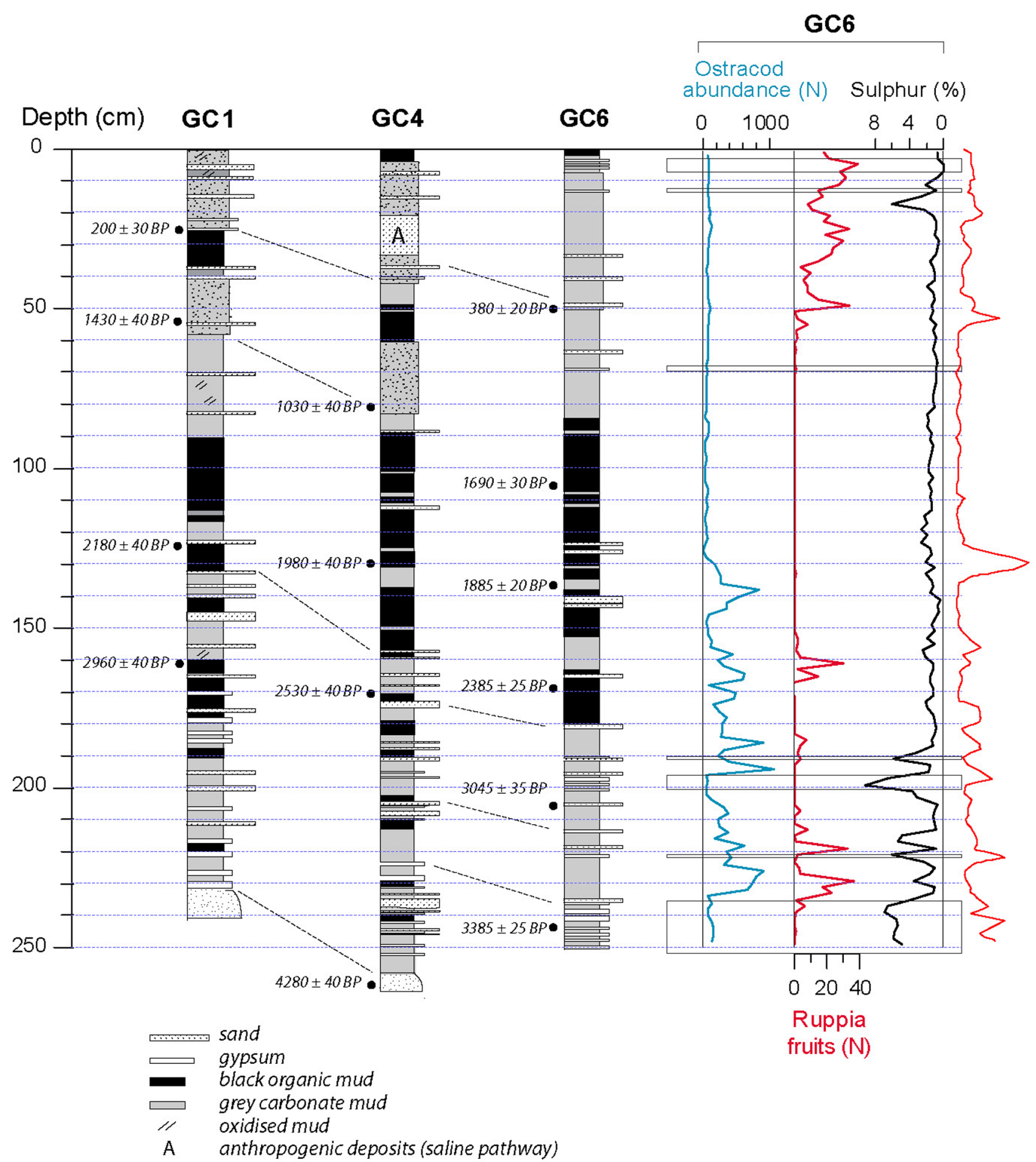

Figure 4. Lithostratigraphy and analytical data of GCI, GC4 and GC6 cores

(2) Ostracod-rich, grey carbonate mud, mostly composed of pellets due to the feeding activity of small Ocypodidae crabs (Uca sp.) (Figure 6a). X-ray analysis shows that carbonates are high magnesian calcite (Figure 7). R. maritima fruits are common to very abundant.

(3) Millimetric laminae of gypsum crystals (Figure 6b). Gypsum forms either disordered concentrations of lensshaped crystals associated with carbonate pellets, due to in situ precipitation, or sorted accumulation of crystals lying flat, that probably reflect redistribution by currents upon storms. X-ray analysis also shows that gypsum is sometimes replaced by, or associated with brushite $\left(\mathrm{CaPO}_{3}(\mathrm{OH})-2 \mathrm{H}_{2} \mathrm{O}\right)$ in the lower part of the core (Figure 7).
(4) Grey sand layers, some millimetres to centimetres in thickness and composed of rounded marine particles (coral and calcareous algae fragments, foraminifera tests) together with low amounts of gypsum crystals and occasional slope-derived angular grains (Figure 6c). The layers are often ungraded or normally graded but some display an inverse grading. One layer (depth $=190$ $\mathrm{cm}$ ) shows ripple cross lamination on x-ray images.

(5) Grey sandy mud, due to diffuse inputs of slope-derived material in the pond. Microscopic examination shows discontinuous submillimetric laminations due to variations in bioclast (mainly ostracod) abundance.

The lithofacies are not evenly distributed, allowing a three-phase history of the sedimentation to be drawn, in relation with fluctuations 
Table I. List of the radiocarbon dates. AMS- ${ }^{14} \mathrm{C}$ dates were made on fruits of Ruppia maritima in GC6 core and calibrated with INTCAL04

\begin{tabular}{lcll}
\hline Lab. no. & Depth (in GC6) (cmbs) & ${ }^{14} \mathrm{C}$ age (BP) & Calibrated age \\
\hline VERA - 4II0 & $50 / 51$ & $380 \pm 20$ & AD I440 (72.4\%) AD I530 AD I570 (23.0\%) \\
& & & AD I630 \\
VERA - 4235 & $105 / 106$ & $1690 \pm 30$ & AD 250 (95.4\%) 420 AD \\
VERA - 4I08 & $138 / 139$ & $1885 \pm 20$ & AD $60(90.5 \%)$ AD I80 AD I90 (4.9\%) AD 220 \\
VERA - 4I07 & $170 / 171$ & $2385 \pm 25$ & $540 \mathrm{BC}(95.4 \%) 390 \mathrm{BC}$ \\
VERA - 4234 & $206 / 207$ & $3045 \pm 35$ & $1410 \mathrm{BC}(95.4 \%) 1210 \mathrm{BC}$ \\
VERA - 4I05 & $244 / 245$ & $3385 \pm 25$ & $1750 \mathrm{BC}(95.4 \%) 1620 \mathrm{BC}$ \\
\hline
\end{tabular}

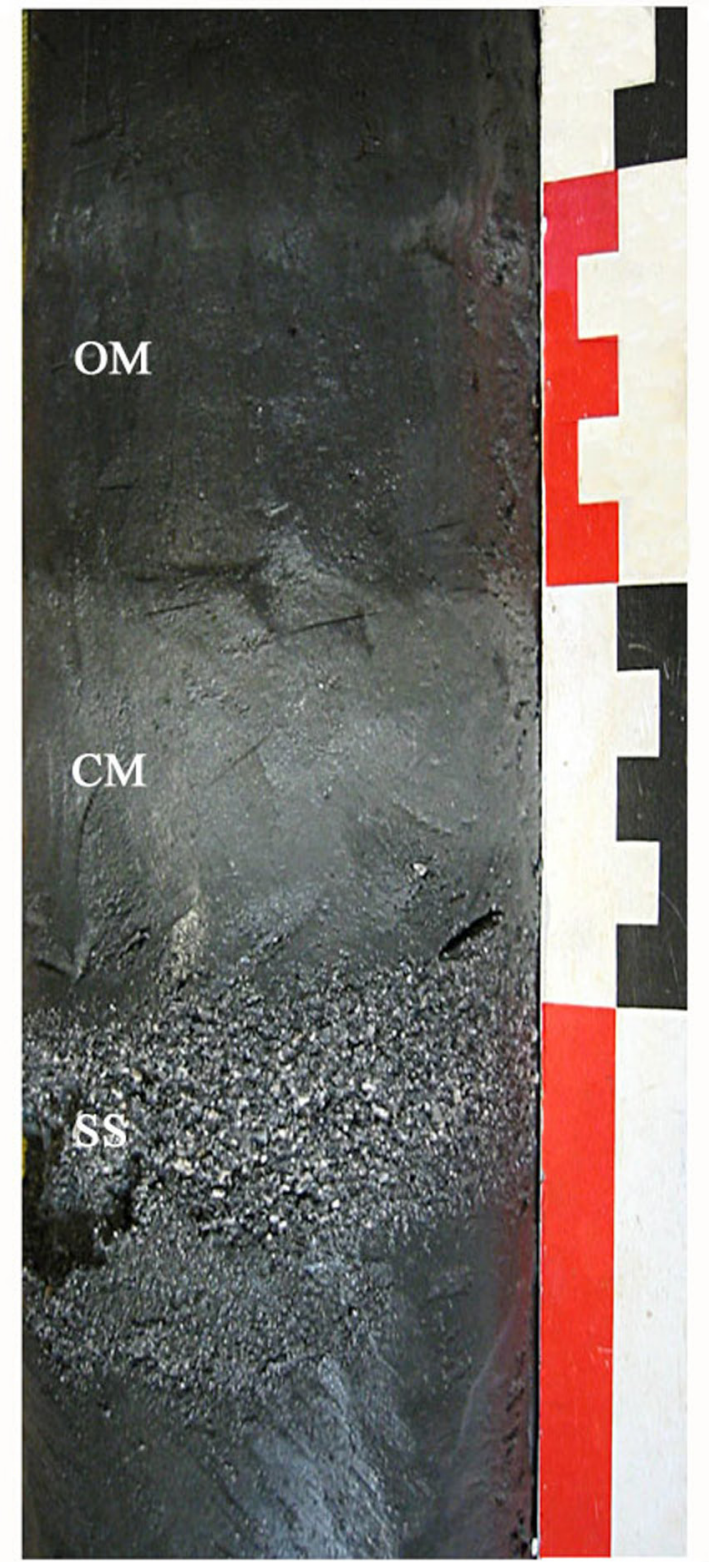

Figure 5. Close up of some lithofacies: OM, organic mud; CM, carbonate mud; SS, storm sand

in the hydrological budget of the pond. Carbonate mud and gypsum/brushite laminae predominate both in the upper (0-85 $\mathrm{cm})$ and lower $(180-250 \mathrm{~cm})$ parts of the core, while organic mud prevails in the middle part. Grey sand layers also tend to concentrate in the carbonate intervals, mainly in the lower part. The general sedimentary sequence is thus very similar to that found previously in $\mathrm{GCl}$ and 4, although precise correlation between layers remains difficult.

\section{Ostracods}

The ostracofauna from Saint-Martin is highly diversified in relation to the variety of available biotopes (subrecifal, coastal, phytal, lagoonal and brackish) (Carbonel et al., 2007). In GrandCase Pond, the fauna is characterised by low diversity and high density. Along most of the core, four to five ostracod species were found for each layer (Carbonel, 2006; Carbonel et al., 2007): three benthic Cyprideis species, the periphytal Perissocytheridea bisulcata (Figure 8A), and Dolerocypria inopinata, a dweller of Ruppia grass (Figure 8B). In the vicinity of the coastal barrier, a mixing of lagoonal and marine species can be observed, the latter being imported with sand into the pond during exceptional storms. This results in a mixed fauna with a lagoonal biocenosis (poor diversity, high density) and a marine thanatocenosis (high diversity, low density). The population of Perissocytheridea bisulcata is very polymorphic with both smooth and reticulate individuals, corresponding to distinct carbonate equilibria at the water-sediment interface (Carbonel and Hoibian, 1988; Peypouquet et al., 1988) as a consequence of seasonal chemical fluctuations in the pond.

Ostracod and Ruppia communities seem to respond to climate-induced environmental factors. Indeed, a strong variability in the abundance of ostracod shells and Ruppia fruits is observed in the basal part of the core (37 up to 1079 ostracod specimens). In the median organic mud layers, from 150 to 60 $\mathrm{cm}$, almost no Ruppia fruits were found, and only few ostracod shells are still present ( 0 to 136 specimens). In the upper part of the core, the abundance of Ruppia fruits increases again, and shows amounts and variability as high as in the basal part of the record (Figure 4), whereas the ostracod abundance remains low. It can be also noticed that in the basal part, each gypsum layer corresponds to a drop in ostracod abundance (Figure 4). This reflects stressful conditions for life in the pond as a consequence of drought and subsequent dramatic increase in salinity and water temperature.

\section{Stable isotope analysis}

The isotopic curves $\left(\delta^{13} \mathrm{C}\right.$ and $\left.\delta^{18} \mathrm{O}\right)$ obtained on the ostracod Perissocytheridea bisulcata are presented on Figure 9. The $\delta^{13} \mathrm{C}$ values are negative all along the core (average $-8 \%$ ), and their fluctuations closely match the lithology. Maximal depletion in ${ }^{13} \mathrm{C}\left(\delta^{13} \mathrm{C}\right.$ between -10 and $\left.-9 \%\right)$ is found for the black organic mud layers.

The oxygen isotopic curve shows stronger variability, which, by contrast to the $\delta^{13} \mathrm{C}$, does not seem to follow the lithology. The $\delta^{18} \mathrm{O}$ values vary between +1.5 and $-1.5 \%$, an isotopic interval already observed for other ostracod species (for example Cytheridella ilosvayi) in mesoamerican lacustrine 


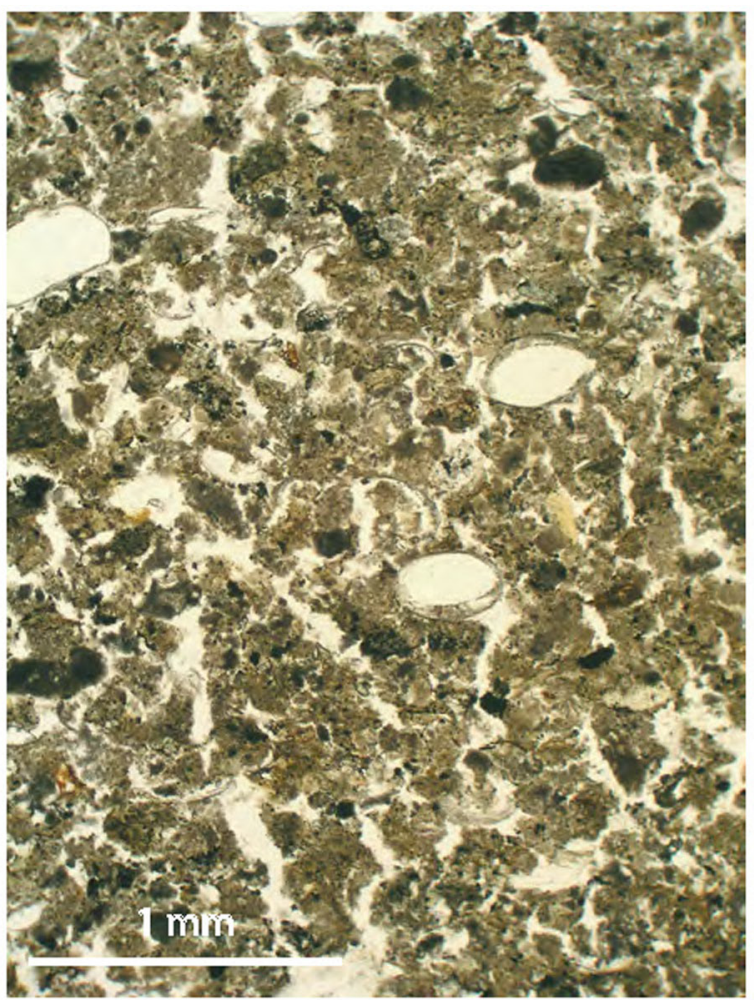

$6 a$

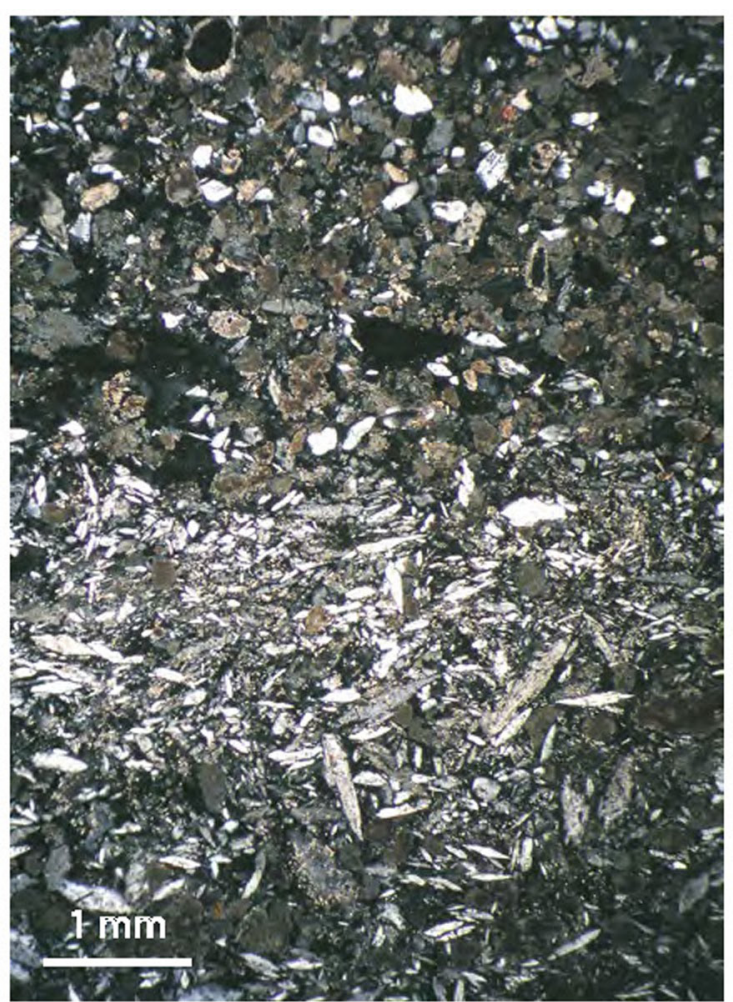

$6 \mathrm{~b}$

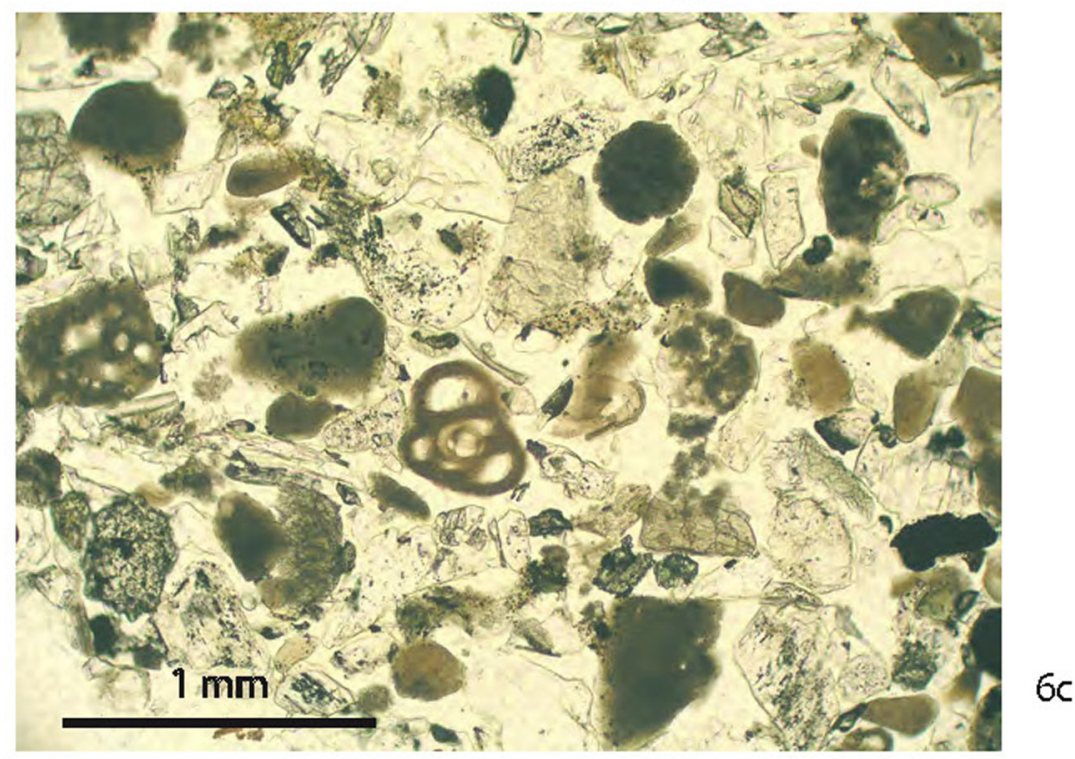

Figure 6. Microfacies. (a) Pelletoidal micritic mud with vegetal fragments and ostracod shells. Thin section, PPL, sample depth: $135 \mathrm{~cm}$. The length covered by the photo is c. $5 \mathrm{~mm}$. (b) Gypsum laminae alternating with micritic mud. Thin section, XPL, sample depth: $242-245 \mathrm{~cm}$. The length covered by the photo is $c$. I cm. (c) Storm sand layer composed of gypsum crystals, rounded calcareous fragments (algae, coral), slope-derived angular grains of quartz and feldspar, and foraminifera. Thin section, PPL, sample depth: $245 \mathrm{~cm}$. The length covered by the photo is $c .4 \mathrm{~mm}$

environments (Curtis et al., 1996). Whereas most of the gypsum layers are associated with positive values, which likely reflect strong evaporation and subsequent concentration of heavy isotopes in the pond, the remaining data do not show any clear pattern but exhibit erratic fluctuations, suggesting that multiple factors are involved in the isotopic composition of water, such as possibly temperature or groundwater inflow in addition to evaporation, which precludes more specific interpretation of the $\delta^{18} \mathrm{O}$ record.

\section{Discussion}

Pond sedimentation model and stable isotopes

Two main modes of 'normal' pond sedimentation can be distinguished, leading to both carbonate mud and evaporite or to pyriterich organic mud deposition. From 3700 to $2500 \mathrm{yr}$ cal. BP, as well as for the last 1150 years, abundant benthic activity (Ocypodidae crabs, ostracods, $R$. maritima) in carbonate layers testifies to well-oxygenated water resulting from regular mixing of 

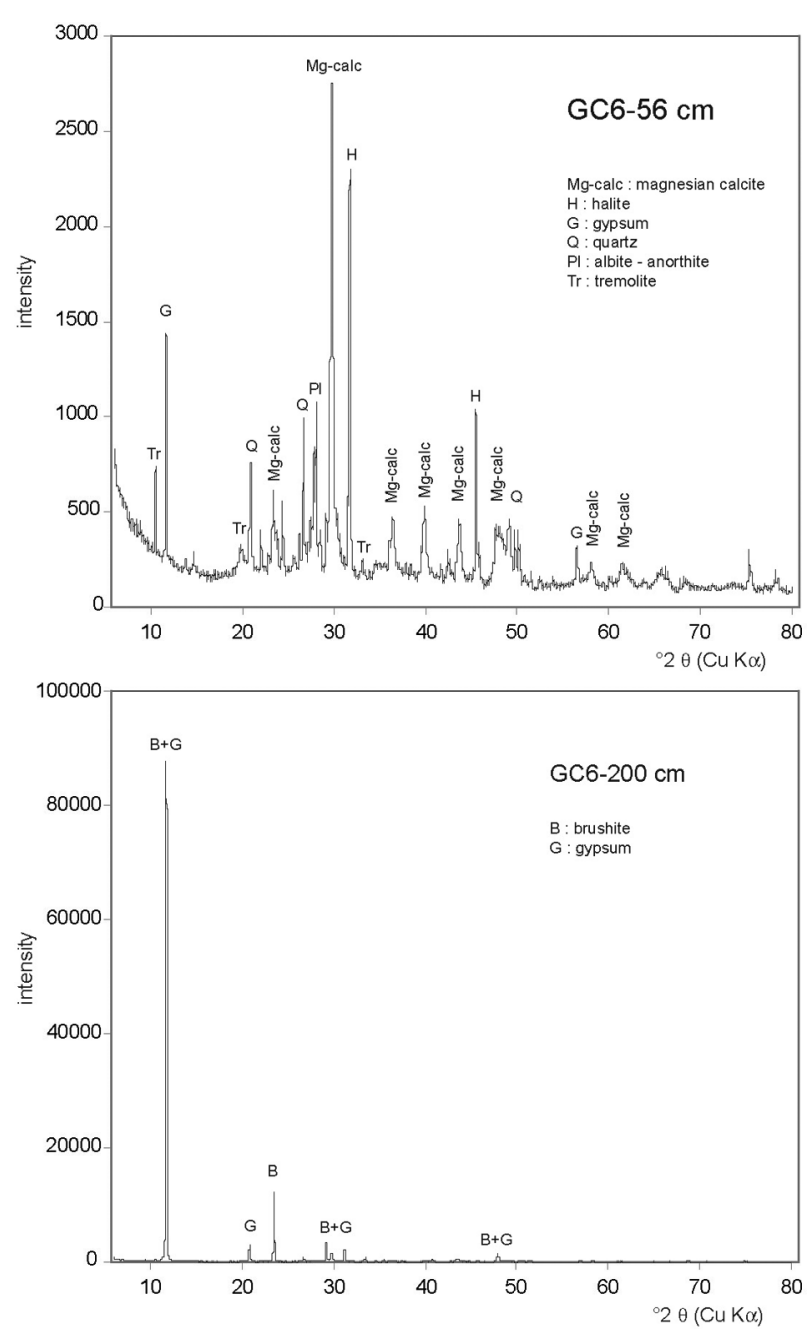

Figure 7. Mineralogical composition of a carbonate mud layer $(\mathrm{GC6}, 56 \mathrm{~cm})$ and an evaporitic layer $(\mathrm{GC6}, 200 \mathrm{~cm})$. Quartz, albiteanorthite, and tremolite derive from the granodiritic substrate, while magnesian calcite, gypsum and brushite are authigenic minerals. Halite is thought to have precipitated during sample drying

the water column, in connection with pond lowstands (Figure 10B). High photosynthesis activity favoured by shallow water promotes saturation with respect to calcite and carbonate precipitation (Kelts and Hsü, 1978), and also strongly influences the

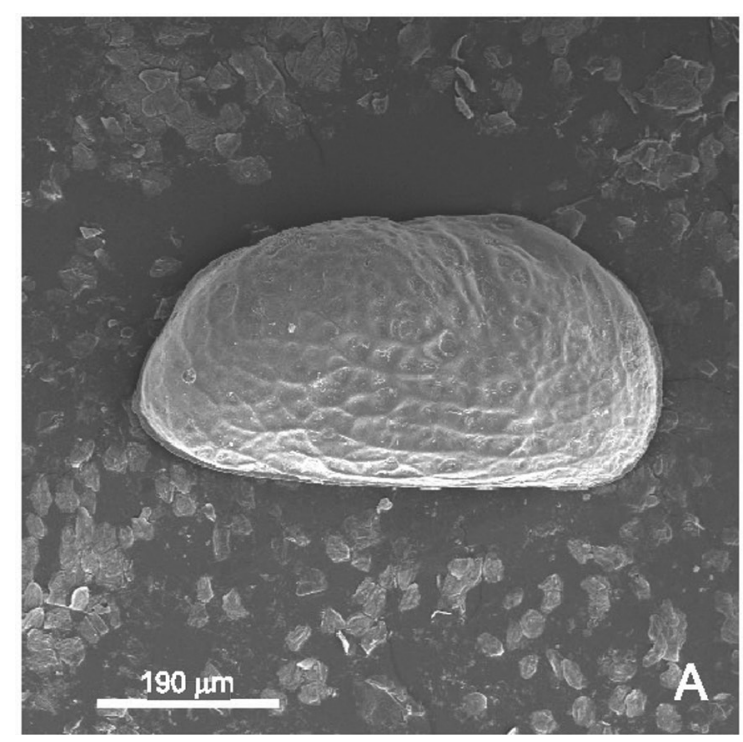

isotopic composition of the dissolved inorganic carbon (DIC) pool, because of preferential incorporation of ${ }^{12} \mathrm{C}$ in the organic matter. This is reflected by the composition of the ostracod Perissocytheridea bisulcata, a periphytal species, which uses the ${ }^{13} \mathrm{C}$-enriched DIC to build its shell. Corresponding ${ }^{13} \mathrm{C}$ values average $-7 \%$ in carbonate mud layers. Such conditions are similar to the present ones, which are typified by the alternation of dry and wet seasons.

Pond lowstands culminate with evaporite deposition. The gypsum-brushite laminae correspond to precipitation from sulphate and phosphate-rich brines onto the pond bottom. According to Rinaudo et al. (1996), gypsum and brushite may precipitate alternatively as a function of $\mathrm{P}$ and $\mathrm{S}$ ionic concentration, at rather low $\mathrm{pH}(<6)$. Lens-shaped gypsum crystals may indicate precipitation within the bottom sediment or the algal mats, as a consequence of the concentration of interstitial water during emersion periods (Magee, 1991; Schreiber et al., 1986). No halite level has been preserved in the record, possibly because of seasonal re-dissolution of the crystals.

Black organic mud deposition occurred mostly between 2500 and $1150 \mathrm{yr}$ cal. BP, and provides little evidence of benthic activity. Particularly, the abundance of both ostracod shells and Ruppia remains was found to be nearly zero in many samples. This, together with the good preservation of terrestrial vegetal debris and sulphide precipitation, indicate that hypoxic to anoxic conditions prevailed most of the year at the bottom of the pond, probably as a consequence of water stratification (Figure 10A). As described by Rosen et al. (1995) and Verschuren (1999) for other saline tropical lakes, density stratification occurs typically during the wet season, when rainfall produces a superficial level of freshwater overlying deeper saline water. This may occur when the water depth exceeds $2-3 \mathrm{~m}$. The density gradient due to the halocline, combined with intense microbial activity and associated oxygen consumption, limits convective mixing of the water and favours development of anoxic conditions at depth. Bacterial decomposition of the organic matter supplied by Ruppia growing in the shallower parts of the pond, and subsequent release of low ${ }^{13} \mathrm{C}$-bearing carbon clearly contributed to shift in the isotopic composition of the DIC, as shown by the ostracod shells. Therefore, the black organic mud layers are characterised by the lowest $\delta^{13} \mathrm{C}$ values ( -9 to $-10 \%$ ) of the whole record (Figure 9). This

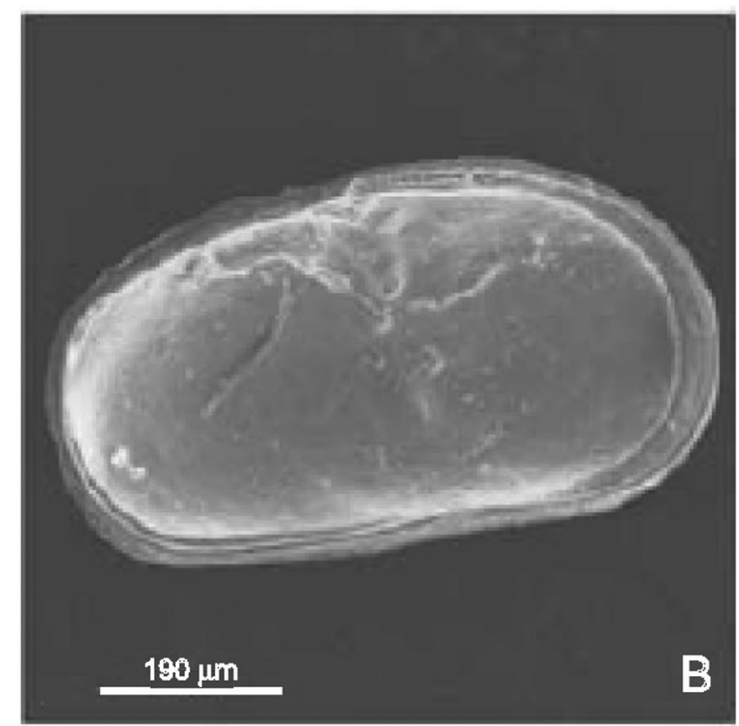

Figure 8. Perissocytheridea bisulcata (A) and Cyprideis sp. 2 aff. C. torosa (B) 


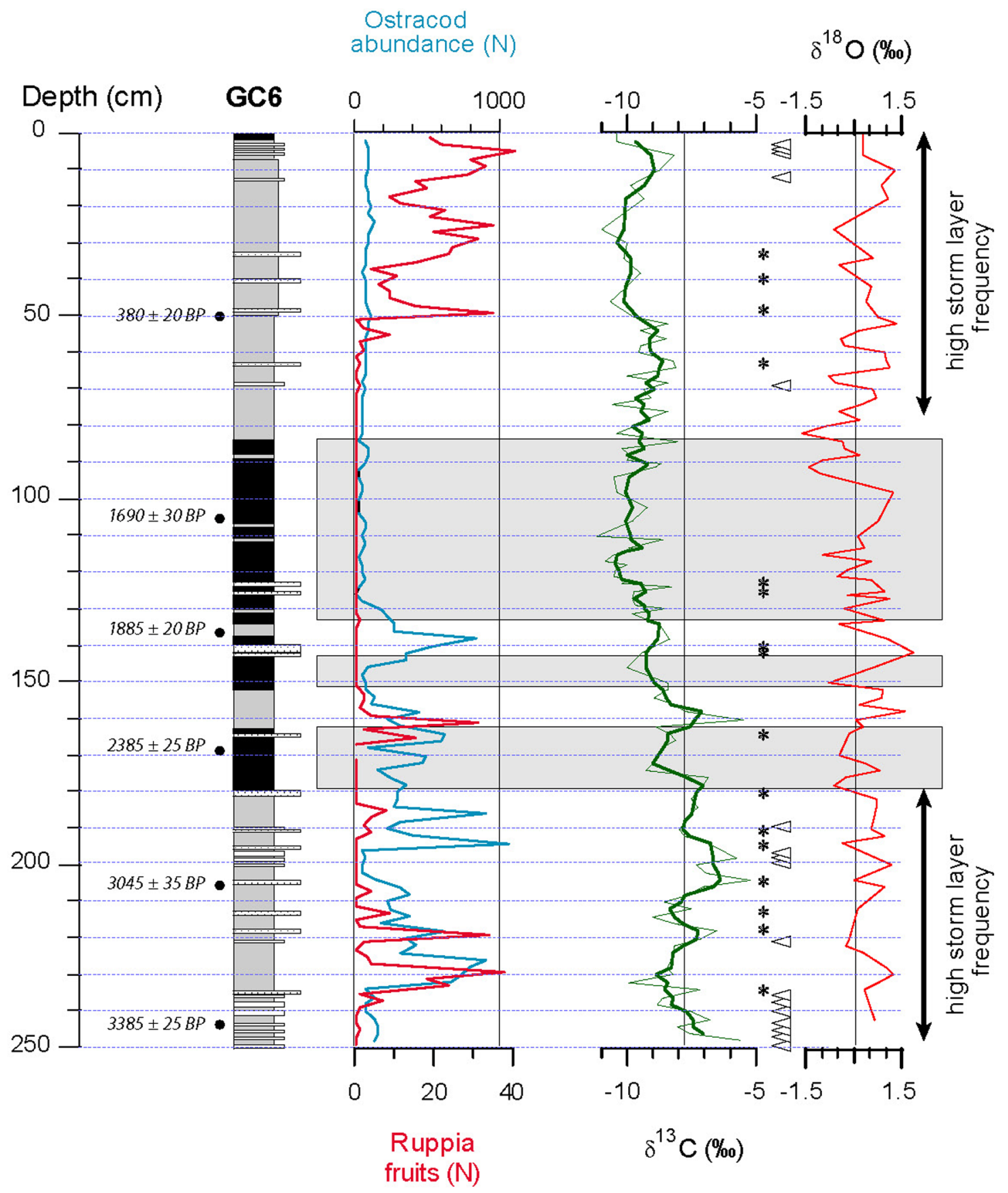

Figure 9. GC6 lithostratigraphy, Ruppia and ostracod abundance, and Perissocytheridea bisulcata isotopic data. The shaded/grey areas correspond to the black organic mud horizons. Stars indicate storm layer occurrence, while arrows underline evaporitic events

lithofacies is thought to be connected with a more or less perennial pond highstand, and reflects wetter and more uniform climatic conditions throughout the year than today.

The 'normal' mud sedimentation is periodically interrupted by the deposition of sand laminae, indicating marine inputs into the pond during storms. The effects of hurricanes on coastal lakes and sand barriers have been described by several authors, amongst others Nummedal et al. (1980) and Stone et al. (2004, 2005) along the Gulf of Mexico, and Rueda (1995) at Grand-Case for hurricane Luis. High waves, in addition to the storm tide, provoke shoreline retreat and opening of the inlets. Overwash of the barrier and inputs through the inlets give birth to fan-shaped sand layers in the backshore lakes (Figure 10C). The layers are typically a few millimetres to $10 \mathrm{~cm}$ thick and show well-developed landward thinning. The aerial photographs of Grand-Case Pond show clearly such a storm fan prograding into the pond from the mouth of the inlet. We cannot exclude that some sand layers correspond to tsunamis. According to Lander et al. (2002), SaintMartin suffered at least two tsunamis in historical times, the first one in 1755 (wave height estimated to $c .4 .5 \mathrm{~m}$, with main effects expected on the Atlantic coast), the other in 1867 (wave height of c. $1.5 \mathrm{~m}$ ). However, for both events, the geomorphological impact seems to have been rather low and did not lead to a written report by the eyewitnesses. Sedimentological evidence, although not definitely conclusive, also supports a storm origin for most of the sand layers. Following Morton et al. (2007), the most important arguments for this interpretation are the lack of rip up clasts and well-sorted sand, indicating that erosion only affected beach 


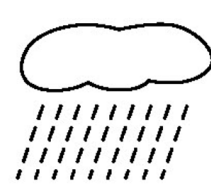

lake highstand

fine-grained particle settling

organic matter production

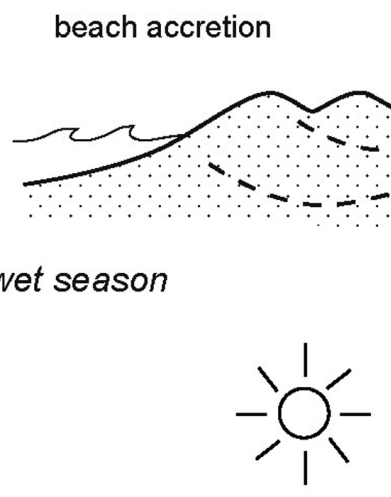

Ruppia

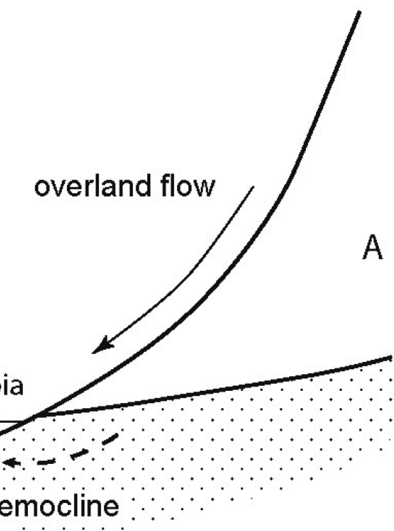

A

mixing, bottom anoxy

- black muds

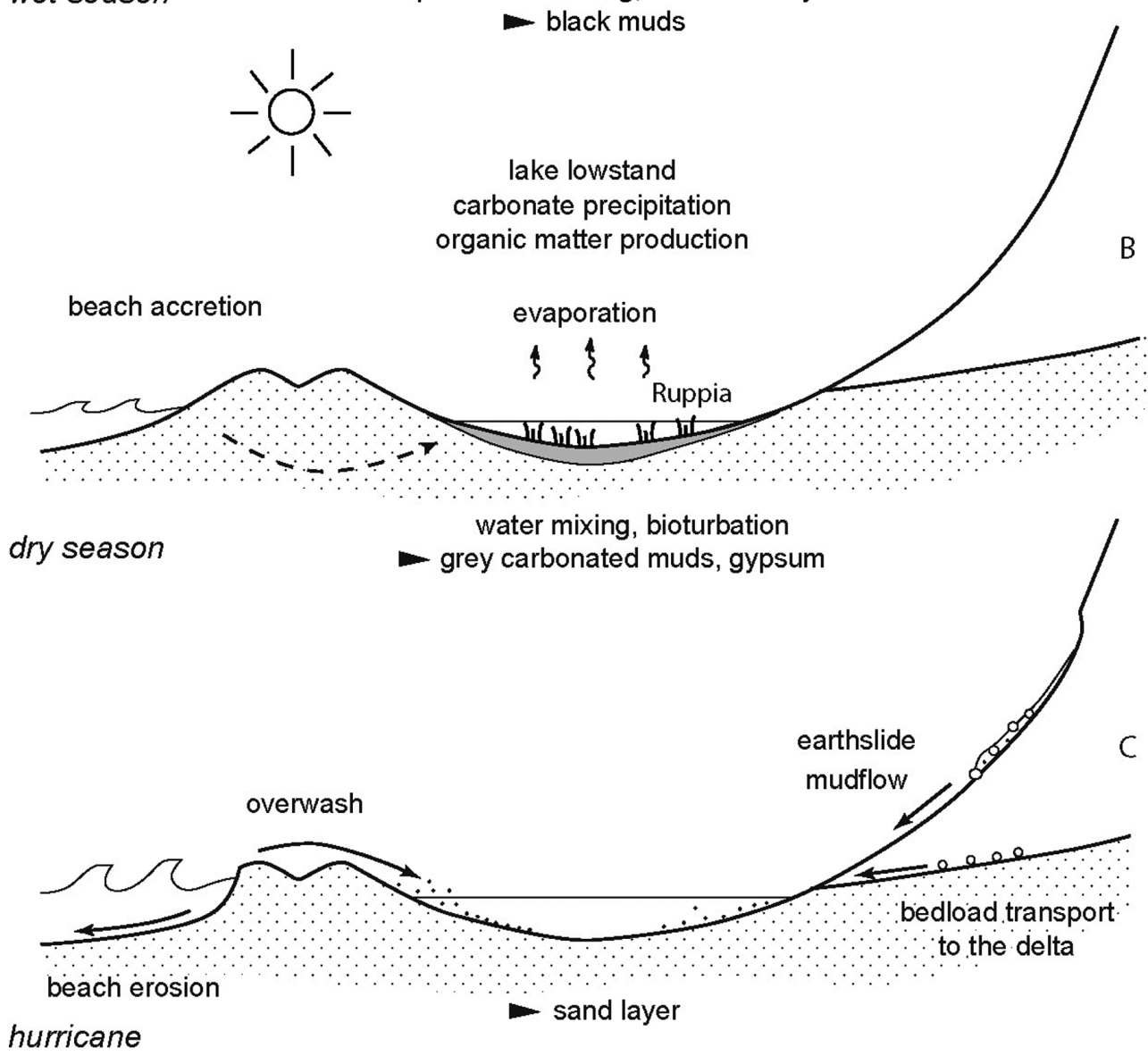

Figure 10. Schematic sedimentation processes at work in the pond

deposits, together with abundant graded beds and occasional ripple lamination due to normal bedload transport in the pond.

Additional coarse-grained inputs into the pond may be also provided by (i) landslides occurring on the steep catchment and triggered by the exceptional rainfall accompanying some hurricanes, and (ii) fluvial transport in the ephemeral stream at the eastern part of the pond, where it gave birth to a small delta. However, both processes had only limited impact on sedimentation at the pond centre as testified by the overwhelming marine origin of the sand particles in the storm layers. Comparison between the recent meteorological data, which indicate 17 hurricane landfalls during the last 100 years at Saint-Martin (i.e. an average of 1 every 6 years), and the cores, where 21 (GC4) and 15 events (GC6) are recorded, shows that only high-intensity hurricanes have significantly contributed to sedimentation. Grain-size fluctuations along the core suggest that other minor overwash events occurred but were not distinguished with the naked eyes, likely because of bioturbation-induced mixing. However, the overall low baseline of sand amounts in the core (except for the upper 50 $\mathrm{cm}$ ) shows that most of the coarse-grained sedimentation was due to few large storm events.

In the upper $50 \mathrm{~cm}$ of the core, lake mud becomes sandier as a result of diffuse slope-derived inputs into the pond, which are thought to result from significant increase in erosion on the catchment and subsequent progradation of shore facies toward the pond centre. Rather good concordance between the initiation of sand deposition (AD 1453-1614, 1 $\sigma$ ) and the known date for European colonisation (c. AD 1610) strongly suggests that erosion was 
a response to intense deforestation of the slopes by the inhabitants, as described by abundant written archives (Association Archéologique Hope Estate, 1996). Unexpectedly low ostracod abundance in the sediments may also result from turbidity increase due to anthropogenic inputs into the pond. In GC1 and GC4, another sandy mud layer occurs respectively at $42-58 \mathrm{~cm}$ and $61-83 \mathrm{~cm}$ in depth. Radiocarbon dates suggest that this layer is time transgressive, start of deposition being bracketed between $\mathrm{AD} 600$ and $651(1 \sigma)$ in $\mathrm{GC} 1$ and $\mathrm{AD} 972$ and 1032 in GC4 located in a deeper part of the pond. This event obviously pre-dates European colonisation and also does not match with a Precolombian occupation documented by archaeology (Bonnissent et al., 2006). Therefore, sandy mud deposition is thought to reflect basinward progradation of subaerial slope deposits in connection with longterm pond lowstand. Building of small overland flow fans at the margin of the pond is similarly observed today during the unusually dry seasons.

\section{General climate pattern in the eastern Caribbean islands}

Three main phases in the hydrological budget of the pond can be distinguished from the GC6 core: (1) a dry period from 3700 to $\sim 2500 \mathrm{yr}$ cal. BP, characterised by the deposition of predominantly carbonate mud and gypsum/brushite layers, (2) a wet phase (2500-1150 yr cal. BP) with monotonous pyrite-rich organic mud in connection to a pond highstand, and (3) a dry phase (1150 yr cal. BP to $400 \mathrm{yr}$ cal. BP; the climate signal is partly obscured in recent times because of pond modification by the European inhabitants), dominated by carbonates, gypsum and detrital inputs due to human activities.

On a regional scale, there are clear parallels between the Grand-Case climatic record and those found around the Caribbean Sea, i.e. a stalagmite in Barbados (Mangini et al., 2007), marine sediments in the Cariaco Basin (Haug et al., 2003; Tedesco and Thunell, 2003), fossil corals and marine sediments from Belize (Gischler and Storz, 2009; Gischler et al., 2008) and pollen data retrieved from Holocene lagoons in Belize (Turneffe islands, Wooller et al., 2009) (Figure 11). In the Cariaco Basin, the bulk titanium (Ti) content of the sediments, linked with the rainfallcontrolled terrigenous delivery to the basin, shows an alternation of humid periods, associated with high Ti concentration, and short and intense droughts characterised by low Ti values $(<0.20 \%)$. This intense climate variability, occurring within two distinct main phases, around 3800 to $2600 \mathrm{yr}$ cal. BP and $1250 \mathrm{yr}$ cal. BP to the present (Haug et al., 2003), is interrupted by a long period of stable medium $\mathrm{Ti}$ values, suggesting a more stable and wetter climate. These results are supported by oxygen isotopic data obtained on planktonic foraminifers in the same basin (Tedesco and Thunell, 2003), which show high frequency of arid conditions between 3800 and 3200, 3000 and $2800 \mathrm{yr}$ cal. BP, and 1200 and $800 \mathrm{yr}$ cal. BP. This three-phase climatic history strongly resembles the findings at Grand-Case. The close fit between evaporite laminae in GC6 and low Ti values at Cariaco indicates that the major drought events occurred simultaneously in both regions (arrows, Figure 11). Other lines of evidence for drier climatic conditions between 3900 and 3300/3200 yr cal. BP are given by peats at Turneffe islands, Belize (pollen data and stable isotopes, Wooller et al., 2009), fossil corals from the Belize barrier reef (stable isotopes, Gischler and Storz, 2009), and speleothems in Barbados (stable isotopes, Mangini et al., 2007) (Figure 11).
Meanwhile, the results from Barbados stalagmite have also revealed the opposite climatic pattern when compared with lacustrine records from Lake Miragoane, in Haiti (Hodell et al., 1991; Mangini et al., 2007). Indeed, within 3800 to $3200 \mathrm{yr}$ cal. BP, highest $\delta^{18} \mathrm{O}$ values recorded in the Barbados speleothem correspond to lowest $\delta^{18} \mathrm{O}$ values recorded in ostracod shells extracted from Miragoane lake, linked with a decrease of the evaporation/ precipitation $(\mathrm{E} / \mathrm{P})$ ratio over the Haitian lake. Extending these opposing climatic patterns to younger ages, higher ostracod $\delta^{18} \mathrm{O}$ values between 2600 and $1600 \mathrm{yr} \mathrm{BP}$, suggesting higher E/P ratio over Haiti, contrast with a wetter climate suggested by southern Caribbean Sea records, from Cariaco Basin to Saint-Martin island, including the Barbados record. To explain this apparent contrast between meteorological conditions between southern and northern parts of the basin, Mangini et al. (2007) have suggested increased seasonality during $\mathrm{NAO}+$ phases, leading to increased precipitation and recharge in Barbados during summer together with cooler winters. Another hypothesis invokes latitudinal shifts of the ITCZ. As suggested by Haug et al. (2003) and Hodell et al. (2005), a northern position of the ITCZ, similar to present summer situation, favours heavy rainfall in the southern part of the Caribbean, together with the Yucatan peninsula, while a southern position, equivalent to the present winter pattern, causes drought all over the Caribbean Sea (Figure 12). A narrowing of the latitudinal influence of the ITCZ might partly explain contrasting meteorological conditions between Haiti and the other southern records of the Caribbean. Significant and abrupt alterations of the seasonal latitudinal migration of the ITCZ, leading to extreme climatic situations, drought included, occurred repeatedly during the oldest and the youngest climatic phases both at Grand-Case and Cariaco, i.e. between 3800 and 2400 yr cal. BP and $1250 \mathrm{yr}$ cal. BP to the present. A more stable northern position of the ITCZ for 2400 to $1250 \mathrm{yr}$ cal. BP might have maintained a long-lasting humid climate in those areas, but not in Haiti (Figure 12a).

For our Saint-Martin's records, storm layers are mainly clustered in the basal unit and, to a lesser extent, in the upper unit of the cores. Such a pattern may be partly driven by the intrinsic evolution of the sand barrier-pond system with time. Widening of the barrier during the Holocene (as documented at Baie Orientale, Saint-Martin, where successive ridges show a landward increasing age, see Bonnissent et al., 2006) leads to a progressive decrease in the number of washovers able to reach the pond. The expected stratigraphic record of this effect would be a regular upward decrease in the frequency of storm layers. This is obviously not the case at Grand-Case, strongly suggesting that millennial-scale fluctuations in hurricane landfalls occurred in the past and are superimposed on the 'normal' evolution of the coast. Comparison between the available records of hurricane landfalls during the last 5000 years in the Caribbean and the Gulf of Mexico area points to significant differences. The data set includes Saint-Martin (this study), the central coast and barrier reef of Belize (Gischler et al., 2008; McCloskey and Keller, 2009), the Vieques island near Puerto Rico (Donnelly and Woodruff, 2007), and a compilation of several records from the US coastline, from Atlantic to western Florida coasts (Mann et al., 2009). Records from Louisiana (Liu and Fearn, 1993, 2000) are more equivocal (Aharon and Lambert, 2009; Otvos, 2002) and not considered in this study. At Saint-Martin, hurricane frequency is higher (more than two times) within the 3700-2500 yr cal. BP time interval, with ten (GC4) and eight (GC6) storm layers for 1200 years, than 
(a)

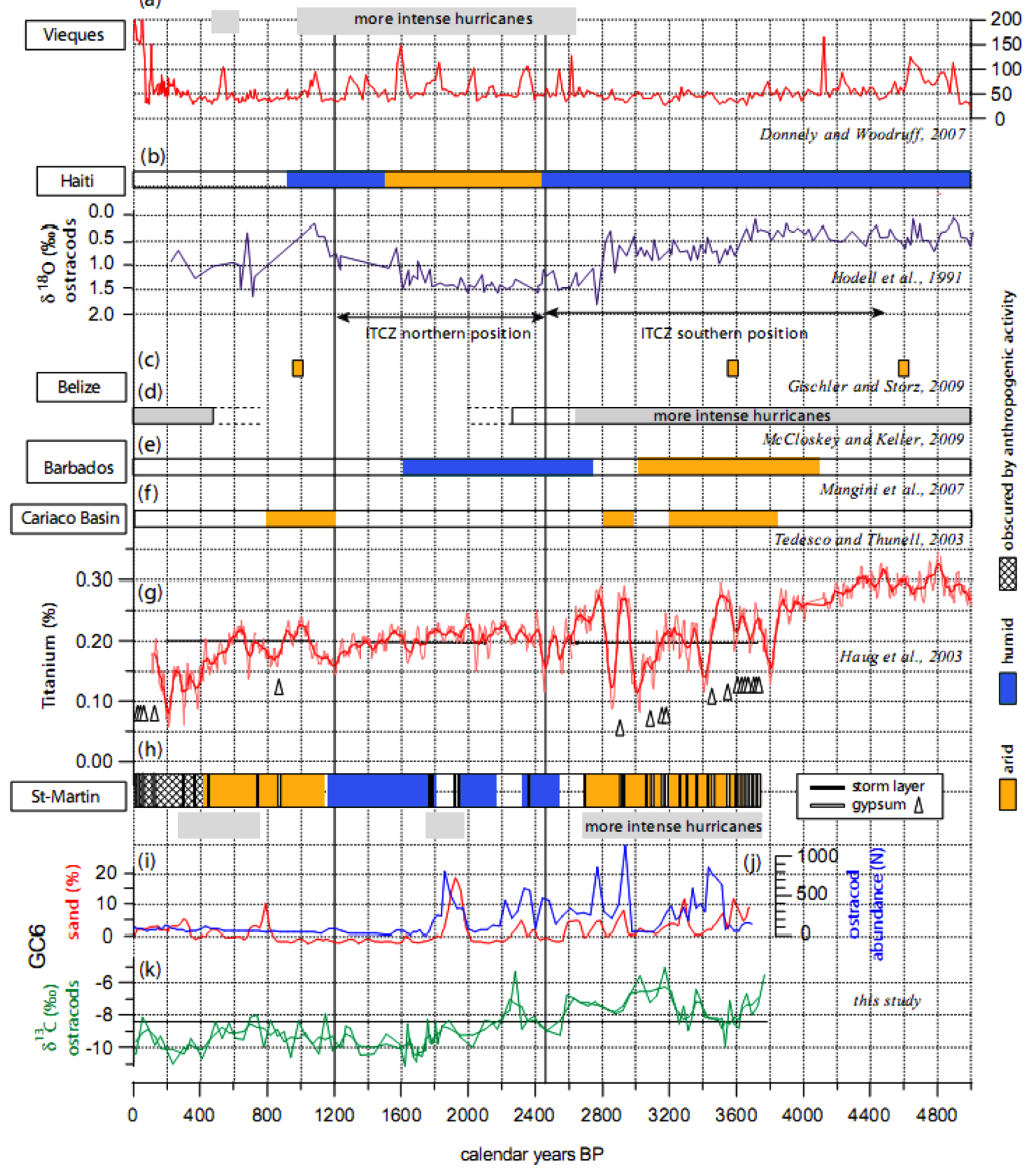

Figure II. Correlations between Saint-Martin and other Caribbean records. (a) Grain size from Viecques LPG4 core, Puerto Rico (Donnelly and Woodruff, 2007). (b) Isotopic composition of ostracods (Candona sp.) from Lake Miragoane, Haiti (Hodell et al., I99I). (c) Climatic data from fossil corals of Belize (Gischler and Storz, 2009). (d) Hurricane strike record from the central coast of Belize (McCloskey and Keller, 2009). (e) Hydrological balance from stalagmite and lake sediment records in Barbados (Mangini et al., 2007). (f) West tropical Atlantic coast climate records from Cariaco Basin (Tedesco and Thunell, 2003). (g) Titanium record from Cariaco Basin (Haug et al., 2003). (h) Hydrological balance and hurricane history at Saint-Martin (this study). (i) Grain size in GC6 core, Saint-Martin (dark curve, this study). (j) Ostracod abundance (grey curve, this study). (k) Carbon isotopic composition of ostracods (this study)

during 2500-1000 yr cal. BP, with only two (GC4) and five (GC6) storm layers for 1500 years (Figure 11). A secondary peak is also observed between 750 and $300 \mathrm{yr}$ cal. BP. Studies from Belize show a close match with the Grand-Case record. McCloskey and Keller (2009) found increased hurricane activity between 5500 and $2500 \mathrm{yr}$ cal. BP, together with an exceptionally strong hurricane (Event 7) at c. $500 \mathrm{yr}$ cal. BP. For the last 1500 years, high-resolution data from a giant sinkhole, the Belize Blue Hole (Gischler et al., 2008), show clusters of hurricane layers at 400 $500,650-750,950$, and $1100-1300$ yr cal. BP. By contrast, at Vieques, the time intervals $3600-2500$ and 1000-250 yr cal. BP are two periods characterised by few intense hurricane strikes, 

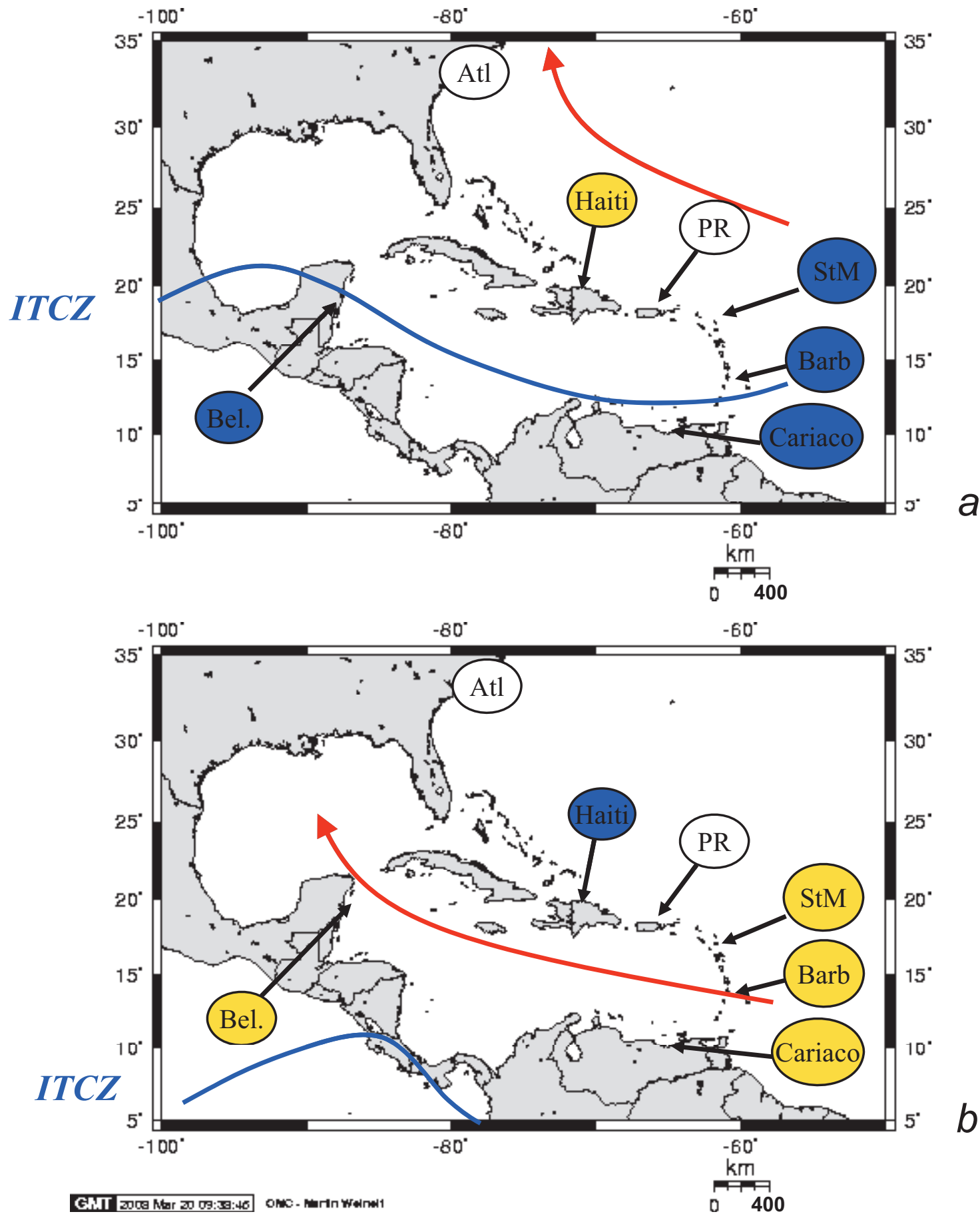

Figure 12. Geographical distribution of typical storm tracks (arrow) in connection with the latitudinal position of the ITCZ. Location of previously studied sites around the Caribbean Sea: Haiti (lake Miragoane, Hodell et al., 1991); Atl (compilation of records on the US Atlantic Coast, Mann et al., 2009); PR (Viecques record, Puerto Rico, Donnelly and Woodruff, 2007); StM (Saint-Martin record, this study); Barb (Barbados record, Mangini et al., 2007); Cariaco (Cariaco Basin record, Tedesco and Thunell, 2003; Haug et al., 2003); Bel. (Belize record, McCloskey and Keller, 2009). Dark grey and light grey indicate, respectively, humid and dry conditions

whereas higher activity is recorded in between. On the US Coast, high activity is suggested during Medieval times, i.e. roughly between AD 900 and 1100 (Mann et al., 2009).

Atmospheric patterns, suggested by paleoclimatic records around the Caribbean Sea, might partly explain contrasting patterns of late-Holocene hurricane frequency (Figure 12). A northern position of the ITCZ is associated with a northward shift of the Bermuda High, favouring the northern migration of hurricane landfalls (Figure 12a). Therefore, more frequent hurricane landfalls are recorded on the US Atlantic coast, and potentially in Puerto Rico, while few hurricanes are recorded in Saint-Martin and Belize. In contrast, a southern position of the ITCZ favours hurricane pathways into the Caribbean Sea, affecting sedimentary records from Saint-Martin to Belize, leaving the US Atlantic coast and Puerto Rico with few hurricane strikes (Figure 12b). This confirms the climatically controlled zone of hurricane landfall, migrating from north to south across the Caribbean (McCloskey and Keller, 2009).

However, the short distance between Saint-Martin and Puerto Rico islands, with contrasting hurricane records, suggests that this concept of a latitudinal shift in hurricane frequency may be too 
simple. Indeed, a longitudinal component might have to be considered, including interrelated atmospheric conditions, such as the North Atlantic Oscillation (NAO) or the El Niño Southern Oscillation (ENSO), as already suggested recently (McCloskey and Keller, 2009). Statistical analysis of the tracks of major hurricanes for the last century by Elsner et al. (2000) provides evidence for a possible NAO influence in the Caribbean area. As demonstrated by Elsner et al. (2000), higher-than-average hurricane activity occurs alternately on the Gulf and the Atlantic side of the American coastline on a multidecadal timescale, such a balance being driven by the NAO. Accordingly, the Gulf coast is more susceptible to a major hurricane landfall during a relaxed NAO index $\left(\mathrm{NAO}^{-}\right)$, whereas the Atlantic side undergoes more frequent hurricanes during an excited NAO index $\left(\mathrm{NAO}^{+}\right)$. Meteorological data for the last 120 years (Pozo-Vasquez et al., 2001) also show that a positive phase of the NAO is related to cold ENSO (La Niña) events. Since NAO effects on the Caribbean climate seem to be dominant on timescales longer than decadal, Mangini et al. (2007) propose a new interpretation of the Cariaco record. They suggest that high Ti amounts thought to indicate a weak ENSO index (Haug et al., 2003), could also be interpreted as a strong NAO index proxy. Low Ti amounts may be linked with a strong ENSO signal and a weak NAO index. The Grand-Case pond record might be influenced by two NAO modes alternating over long periods during the last 5000 years. The $2400-1250 \mathrm{yr}$ interval corresponds to a predominant $\mathrm{NAO}^{-}$type period, while the preceding and following time intervals were dominantly of $\mathrm{NAO}^{+}$type.

\section{Conclusions}

The multiproxy analysis of Grand-Case Pond at Saint-Martin, north of the Lesser Antilles, provides novel information on the palaeoclimatology of the area during the past 4000 years BP. Two main sedimentation modes can be distinguished: (i) a lowstand situation, allowing a varied biotope to develop in the pond, with occasional evaporitic events due to severe drought episodes, (ii) a more or less perennial pond highstand, reflecting wet and uniform climatic conditions, and characterised by low biological activity. Pyrite-rich organic mud deposition occurred in connection with pond highstands and indicates hypoxic to anoxic conditions in the bottom of the pond due to long-lasting water stratification.

Isotopic measurements made, for the first time, on the ostracod Perissocytheridea bisulcata highlight the potential of this species for palaeoclimatic reconstructions. Although the $\delta^{18} \mathrm{O}$ record shows strong variability, probably because of the diversity of influencing factors up to now imperfectly understood, the $\delta^{13} \mathrm{C}$ is in agreement with the sedimentation model proposed and shows very low values during anoxic phases due to bacterial recycling of isotopically depleted organic matter.

Sand layers, which testify to intense hurricane landfalls, are not evenly distributed in the core, but occur with a high frequency during the dominantly dry (lowstand) periods, i.e. between 3700 and $2500 \mathrm{yr}$ cal. BP and from $1150 \mathrm{yr}$ cal. BP to the present. These periods coincide with the time intervals of major hurricane activity recorded in the central coast of Belize (McCloskey and Keller, 2009) and to strong climate variability recorded in the Cariaco Basin (Haug et al., 2003; Tedesco and Thunell, 2003). However, they are in full opposition to the phases of major hurricane activity previously described for Puerto Rico area, where most of the storm events occurred between 2500 and $1000 \mathrm{yr}$ cal. BP
(Donnelly and Woodruff, 2007), and for US Atlantic coast, with higher activity around $1000 \mathrm{yr}$ BP.

Two atmospheric patterns could explain this apparent contradiction. On a latitudinal gradient, a southern migration of the ITCZ favours drier conditions on the southern Caribbean Sea, together with a southern hurricane strike pathway. Such a climatic pattern might have controlled the southern Caribbean Sea during 3700$2500 \mathrm{yr}$ cal. BP time interval and from $1150 \mathrm{yr}$ cal. BP to the present. For the 2500-1150 yr cal. BP time interval, a northward migration of the ITCZ might have reversed the pattern, hurricane strikes hitting more specifically the US Atlantic coast, leaving the southern Caribbean Sea in a more stable and humid climate. In addition to this latitudinal control, a longitudinal component might also have played an important role, linked with the NAO as suggested by meteorological observations from the last century, analyzed by Elsner et al. (2000). When higher-than-average hurricane activity is recorded on the Atlantic coast, lower-than-average activity takes place in the Caribbean Sea and the Gulf of Mexico, and vice versa. The two modes should be linked with the NAO, a relaxed NAO leading to stronger storm activity on the Gulf coast, while an excited NAO favours hurricanes on the Atlantic coast. We propose that such an opposition held for the past 4000 years.

\section{Acknowledgements}

Financial support was provided by 'Région Guadeloupe', 'Direction Régionale des Affaires Culturelles (DRAC Guadeloupe)', and the PCR entitled 'Paleoenvironnements et occupations amérindiennes de l'île de Saint-Martin (Petites Antilles)'. The authors would like to thank Jean Carlos Montero-Serrano, Xavier Crosta and Thierry Corrège for fruitful discussion, Olivier Ther for preparation of the ostracod samples and H. Etcheber for Organic Carbon analysis. In addition, fruitful comments from the associate editor, Joe Mason, and from two anonymous reviewers, have strongly contributed to improve the manuscript. This paper is contribution number 1740 of UMR 5805 EPOC.

\section{References}

Aharon P and Lambert WJ (2009) Radiocarbon deficiencies of US Gulf Coast lakes compromise paleo-hurricane records. Quaternary Research 71: 266-270.

Angulo RJ and Lessa GC (1997) The Brazilian sea-level curves: A critical review with emphasis on the curves from the Paranagua and Cananéia regions. Marine Geology 140: 141-166.

Association Archéologique Hope Estate (1996) Recueil d'archives historiques concernant les îles de St. Martin et St. Barthélémy, 1717-1938. Marigot: Musée Archéologique de Saint-Martin, 129 pp.

Bertran P, Bonnissent D, Imbert D, Lozouet P, Serrand N and Stouvenot Ch (2004) Paléoclimat des Petites Antilles depuis 4000 ans BP: l'enregistrement de la lagune de Grand-Case à Saint-Martin. Comptes Rendus Geoscience 336: 1501-1510.

Bonnissent D, Bertran P, Carbonel P and Imbert D (2006) Modifications des paléoenvironnements et occupations amérindiennes de l'île de SaintMartin (Petites Antilles). Basse-Terre, Guadeloupe: Service régional de 1'Archéologie, Unpublished report, 53 pp.

Carbonel P (2006) Bilan des recherches effectuées avec les ostracodes en 2006. In: Bonnissent D (ed.) Modifications des paléoenvironnements et occupations amérindiennes de l'île de Saint-Martin (Petites Antilles). Basse-Terre, Guadeloupe: Service régional de l'Archéologie, Unpublished report, 26-35.

Carbonel P and Hoibian T (1988) The impact of organic matter on ostracods from an equatorial deltaic area: The Mahakam delta-Southeastern kalimantan. In: Hanai T, Ikeya N and Ishizaki K (eds) Evolutionary Biology of Ostracoda. Elsevier, 353-366.

Carbonel P, Penne A, Bertran P, Bonnissent D, Galop D, Imbert D et al. (2007) Saint-Martin (Antilles), ostracodes et milieux actuels. Données générales. Bulletin de la Societé Linneenne de Bordeaux 142(35/4): 455-470. 
Curtis J-H, Hodell DA and Brenner M (1996) Climate variability on the Yucatan peninsula (Mexico) during the past 3500 years, and implications for Maya cultural evolution. Quaternary Research 46: 37-47.

Donnelly J-P (2005) Evidence of past intense tropical cyclones from backbarrier salt pond sediments: A case study from Isla de Culebrita, Puerto Rico, USA. Journal of Coastal Research 142: 201-210.

Donnelly JP and Woodruff JD (2007) Intense hurricane activity over the past 5,000 years controlled by El Niño and the West African monsoon. Nature 447: 465-468.

Donnelly JP, Butler J, Roll S, Wengren M and Webb T III (2004) A backbarrier overwash record of intense storms from Brigantine, New jersey. Marine Geology 210: 107-121.

Elsner J-B, Liu KB and Kocher B (2000) Spatial variations in major U.S.Hurricane Activity: Statistics and a physical mechanism. Journal of Climate 13: 2293-2305.

Emery KO (1969) A Coastal Pond Studied by Oceanographic Methods. New York: American Elsevier Publishing.

Gischler E and Storz D (2009) High-resolution windows into Holocene climate using proxy data from Belize corals (Central America). Palaeobiology, Palaeoenvironment 89: 211-221.

Gischler E, Shinn EA, Oschmann W, Fiebig J and Buster NA (2008) A 1500year Holocene Caribbean climate archive from the Blue Hole, Lighthouse reef, Belize. Journal of Coastal Research 24(6): 1495-1505.

Haug G, Günther D, Peterson L, Sigman D, Hughen K and Aeschlimann B (2003) Climate and the collapse of Maya civilization. Science 299: 1731-1735.

Hodell D, Brenner M and Curtis J (2005) Terminal classic drought in the northern Maya lowlands inferred from multiple sediment cores in Lake Chichancanab (Mexico). Quaternary Science Reviews 24: 1413-1427.

Hodell D, Curtis J, Jones G, Higuera-Gundy A, Brenner M, Binford M et al (1991) Reconstruction of Caribbean climate change over the past 10,500 years. Nature 352: 790-793.

K lts KR and Hsü KJ (1978) Freshwater carbonate sedimentation. In: Lerman A (ed.) Lakes: Chemistry, Geology, Physics. New York: Springer Verlag, 295-333.

Lambert WJ, Aharon P and Rodriguez AB (2003) An assessment of the late Holocene record of severe storm impacts from lake Shelby, Alabama. Transaction-Gulf Coast Association of Geological Societies 53: 443.

Lambert WJ, Aharon P and Rodriguez AB (2008) Catastrophic hurricane history revealed by organic geochemical proxies in coastal lake sediments: A case study of lake Shelby, Alabama(USA). Journal of Paleolimnology 39: 117-131.

Lander JF, Whiteside LS and Lockridge PA (2002) A brief history of tsunamis in the Caribbean Sea. Science of Tsunami Hazards 20(2): 57-94.

Liu K and Fearn ML (1993) Lake-sediment record of late Holocenee hurricane activities from coastal Alabama. Geology 21: 793-796.

Liu K and Fearn ML (2000) Reconstruction of prehistoric landfall frequencies of catastrophic hurricanes in northwestern Florida from lake sediment records. Quaternary Research 40: 332-342.

Magee JW (1991) Late Quaternary lacustrine, groundwater, aeolian and pedologic gypsum in the Prungle Lakes, southeastern Australia. Palaeogeography, Palaeoclimatology, Palaeoecology 84: 3-42.

Mangini A, Blumbach P, Verdes P, Spötl C, Scholz D, Machel S et al. (2007) Combined records from a stalagmite from Barbados and from lake sediments in Haiti reveal variable seasonality in the Caribbean between 6.7 and 3ka B.P. Quaternary Science Reviews 26: 1332-1343.

Mann ME, Woodruff JD, Donnelly D and Zhang Z (2009) Atlantic hurricanes and climate over the past 1,500 years. Nature 460: 880-885, doi:10.1038/ nature 08219 .
McCloskey TA and Keller G (2009) 5000 year sedimentary record of hurricane strikes on the central coast of Belize. Quaternary international 195: 53-68.

Milne GA, Long JL and Bassett SE (2005) Modelling Holocene relative sealevel observations from the Caribbean and South America. Quaternary Science Reviews 24: 1183-1202.

Morton R, Gelfenbaum G and Jaffe BE (2007) Physical criteria for distinguishing sandy tsunami and storm deposits using modern examples. Sedimentary Geology 200: 184-207.

Nummedal D, Penland S, Gerdes R, Schramm W, Kahn J and Roberts H (1980) Geologic response to hurricane impact on low-profile Gulf coast barriers. Transactions of the Gulf Coast Association Geological Society XXX: 183-195.

Otvos EG (2002) Discussion of 'Prehistoric Landfall frequencies of catastrophic hurricanes...'(Liu and Fearn, 2000). Quaternary Research 57: 425-428.

Otvos EG (2005) Holocene aridity and storm phases, Gulf and Atlantic coasts, USA. Quaternary Research 63: 368-373.

Peypouquet J-P, Carbonel P, Ducasse O, Farmer M and Lété C (1988) Environmentally cued Polymorphism of ostracods. In: Hanai T, Ikeya $\mathrm{N}$ and Ishizaki K (eds) Evolutionary Biology of Ostracoda. Elsevier, 353-366.

Pozo-Vasquez D, Esteban-Parra M-J, Rodrigo F-S and Castro-Diez Y (2001) The association between ENSO and winter atmospheric circulation and temperature in the North Atlantic Region. Journal of Climate 14: 3408-3420.

Rinaudo C, Lanfranco AM and Boistelle R (1996) The gypsum-brushite system: Crystallization from solutions poisoned by phosphate ions. Journal of Crystal Growth 158: 316-321.

Rosen MR, Turner JV, Coshell L and Gailitis V (1995) The effects of water temperature, stratification, and biological activity on the stable isotopic composition and timing of carbonate precipitation in a hypersaline lake. Geochimical Cosmochimical Acta 59: 979-990.

Rueda F (1995) Saint-Barthelemy, Saint-Martin. Rapport de mission. Sète: Préfecture de la région Languedoc-Roussillon, Service Maritime et de Navigation du Languedoc-Roussillon, Unpublished report, 53 pp.

Schreiber BC, Tucker ME and Till R (1986) Arid shoreline and evaporites. In: Reading HG (ed.) Sedimentary Environments and Facies. Oxford: Blackwell, 189-228.

Stone GW, Liu B, Pepper DA and Wang P (2004) The importance of extratropical and tropical cyclones on the short-term evolution of barrier islands along the northern Gulf of Mexico, USA. Marine Geology 210: 63-78.

Stone GW, Walker ND, Hsu SA, Babin A, Liu B, Keim BD et al. (2005) Hurricane Ivan's impact along the northern Gulf of Mexico. EOS 86(48): 497-508.

Tedesco K and Thunell R (2003) High resolution tropical climate record for the last 6,000 years. Geophysical Research Letters 30(17): 1891, doi:10.1029/2003GL017959.

Verschuren D (1999) Sedimentation controls on the preservation and time resolution of climate-proxy records from shallow fluctuating lakes. Quaternary Science Reviews 18: 821-837.

Woodruff JD, Donnelly D, Emanuel K and Lane P (2008a) Assessing sedimentary records of paleo-hurricane activity using modelled hurricane climatology. Geochemistry, Geophysics, Geosystems 9: Q09V10, doi: 10.1029/2008GC002043.

Woodruff JD, Donnelly D, Mohrig D and Geyer WR (2008b) Reconstructing relative flooding intensities responsible for hurricane-induced deposits from Laguna Playa Grande, Vieques, Puerto Rico. Geology 36: 391-394.

Wooller MJ, Behling H, Guerrero J-L, Jantz N and Zweigert M (2009) Late Holocene hydrologic and vegetation changes at Turneffe atoll, Belize, compared with records from mainland Central America and Mexico. Palaios 24: 650-656. 